\title{
Analisis Penerimaan dan Penggunaan A plikasi Work Order Android Menggunakan Metode UTAUT Pada PDAM Kota Malang
}

\author{
Ika Winda Kusumawardani ${ }^{{ }^{1}}$, Evi Dwi Wahyuni ${ }^{2}$, Wildan Suharso ${ }^{3}$ \\ ${ }^{1,2,3}$ Universitas Muhammadiyah Malang \\ adniwika18@gmail.com
}

\begin{abstract}
Abstrak
Work Order Android (Wondroid) merupakan sebuah aplikasi surat perintah kerja yang dikembangkan pada PDAM Kota Malang untuk memudahkan realisasi pekerjaan. Tetapi tidak selalu aplikasi yang diterapkan mendapatkan tanggapan baik. Faktor pengguna dapat menentukan keberhasilan penerapan sebuah aplikasi. Untuk dapat mengetahui penerimaan dan penggunaan aplikasi Wondroid, digunakan model UTAUT. UTAUT adalah model penerimaan teknologi dari gabungan delapan model sebelumnya. Penelitian ini membuktikan pengaruh variabel bebas (Ekspektasi Kinerja, Ekspektasi Usaha, Pengaruh Sosial dan Kondisi Memfasilitasi) terhadap variabel terikat (Niat Perilaku dan Perilaku Pengguna) secara parsial maupun simultan. Pengambilan data menyertakan 100 responden dari pengguna Wondroid. Analisis pengolahan data dibantu dengan aplikasi statistik SPSS. Hasil penelitian menunjukkan bahwa terdapat pengaruh positif maupun negatif. Ekspektasi Kinerja terbukti tidak berpengaruh terhadap Niat Perilaku, sedangkan Ekspektasi Usaha dan Pengaruh Sosial berpengaruh positif dan signifikan terhadap Niat Perilaku. Kondisi yang Memfasilitasi dan Niat perilaku berpengaruh positif dan signifikan terhadap Perilaku Pengguna. Hasil analisis keseluruhan membutktikan Niat Perilaku memperoleh 34,7\% yang dipengaruhi oleh variabel Ekspektasi Kinerja, Ekspektasi Usaha dan Pengaruh Sosial.
\end{abstract}

\section{Kata kunci: Metode UTAUT, User Acceptance, Work Order Android}

PENDA HULUAN

Suatu organisasi maupun perusahaan tidak bisa lepas dari pengaruh teknologi informasi yang fungsinya dapat meningkatkan sarana kualitas pelayanan internal maupun eksternal. Teknologi informasi juga berperan dalam mengatasi kendalakendala yang berkaitan dengan efektivitas pekerjaan dalam suatu organisasi maupun perusahaan. Tetapi aplikasi yang diterapkan tidak selalu mendapatkan tanggapan baik. Faktor pengguna dapat menentukan keberhasilan penerapan sebuah aplikasi. Sejauh ini masih sedikit programmer yang melakukan analisis sistem informasi. Untuk dapat mengetahui sebesar apa pengaruh teknologi informasi tersebut dapat diterima oleh user adalah dengan melakukan analisis sistem. Menurut Kristanto (2003), analisis sistem untuk memperbaiki suatu sistem informasi yang melewati proses akumulasi kondisi ataupun peristiwa kemudian menggambarkan kenyataan tersebut.
Perkembangan teknologi menjadi suatu tuntutan pada perusahaan pelayanan publik, PDAM telah menerapkan aplikasi Work Order Android (Wondroid) yang sudah berjalan 5 tahun. Alasan aplikasi Wondroid dibuat untuk memudahkan pegawai PDAM Kota Malang dalam realisasi pekerjaan. Namun, tak semua teknologi informasi yang diterapkan dikatakan sukses. Untuk itu tujuan dari penelitian ini menjelaskan faktor-faktor yang berpengaruh terhadap penerimaan pengguna aplikasi Wondroid pada PDAM Kota Malang menggunakan metode UTAUT.

Penelitian serupa dilakukan oleh Siska Iriani pada tahun 2014 yang menguji penerimaan sistem informasi pengelola keuangan daerah di Kabupaten Pacitan dengan hasil SIPKD diterima pengguna dengan persentase sebesar 65\% [3]. Penelitian dilakukan oleh Fandhilah pada tahun 2015 dengan tujuan untuk mengetahui penerimaan program aplikasi akuntansi pada SMK Yadika 1 dan 2. Hasil penelitian menunjukkan 66\% [1]. Penelitian 
selanjutnya dilakukan oleh Nur Ali Farabi pada tahun 2016. Penelitian bertujuan untuk mengetahui faktorfaktor yang mempengaruhi penerimaan dan penggunaan SIZISW. Hasilnya SIZISW tidak dipengaruhi oleh Effort Expectancy, sedangkan faktor Performance Expectancy, Social Influence dan Facilitating Conditions dinyatakan berpengaruh [2].

Sebagai salah satu aplikasi yang diterapkan di perusahaan, aplikasi Wondroid harus dapat diterima oleh pengguna. Sebuah model pengembangan penerimaan teknologi informasi dilakukan oleh Venkatesh, et al. (2003) model tersebut adalah Theory of Acceptance and Use of Technology (UTAUT). UTAUT menjelaskan bahwa Niat Perilaku dipengaruhi oleh Ekspektasi Kinerja, Ekspektasi Usaha dan Pengaruh Sosial sedangkan Perilaku Pengguna dipengaruhi oleh kondisi yang memfasilitasi yang dimoderatori oleh Usia, Jenis Kelamin, Pengalaman dan Kesukarelaan Menggunakan Sistem. Penggunaan teknologi informasi dapat menjabarkan perilaku penerimaan pengguna sebesar 70 persen (Venkatesh, et. al) [7].

Penelitian ini bertujuan untuk mengetahui variabel Niat Perilaku dan Perilaku Pengguna yang dipengaruhi oleh variabel Ekspektasi Kinerja, Ekspektasi Usaha, Pengaruh Sosial dan Kondisi-Kondisi Memfasilitasi secara parsial maupun simultan. Pada hasil penelitian ini, diharapkan pihak PDAM Kota Malang khususnya pada bagian Sistem Informasi Manajemen dapat menentukan kebijakan pengembangan aplikasi Work Order Android (Wondroid) selanjutnya.

\section{METODE PENELITIAN}

Dalam penelitian ini, peneliti ini mengetahui apakah terdapat pengaruh positif ataupun negatif dan signifikan antara dua variabel atau lebih, serta mengetahui hubungan yang ada antara variabel. Untuk menjawab permasalahan tersebut peneliti melakukan pembuktian hipotesis. Penelitian ini menerapkan pendekatan kuantitatif secara survei. Sampel yang akan digunakan Langkah awal yang dilakukan ialah pengumpulan data awal dilakukan dengan observasi ke tempat penelitian dan melakukan wawancara terkait dengan masalah penelitian. Tahapan penelitian ditunjukkan pada Gambar 1.

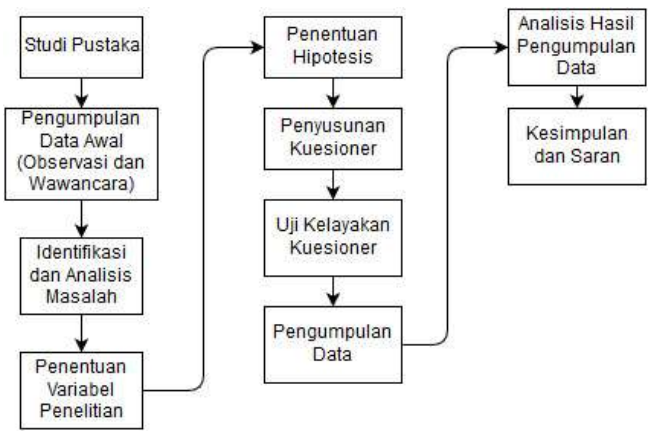

Gambar 1. Tahap Penelitian

Penentuan Variabel Penelitian

Menurut Sugiyono (2011) variabel penelitian merupakan sifat, nilai, obyek, atribut maupun kegiatan yang telah ditentukan oleh peneliti untuk diolah sehingga dapat ditarik kesimpulan secara ringkas [9]. Dalam penelitian ini variabel independen yang digunakan adalah Ekspektasi Kinerja, Ekspektasi Usaha, Pengaruh Sosial dan KondisiKondisi Memfasilitasi Sementara variabel dependen adalah Niat Perilaku dan Perilaku Pengguna.

Model konseptual UTAUT yang digunakan dalam penelitian ini dapat dilihat pada Gambar 2, meliputi Ekspektasi Kinerja (Performance Expectancy), Ekspektasi Usaha (Effort Expectancy), Pengaruh Sosial (Social Influence), Kondisi-kondisi Memfasilitasi (Facilitating Conditions), Niat Perilaku (Behavioral Intention) dan Perilaku Pengguna (Use Behavior).

\section{Penentuan Hipotesis}

Dalam makalah ini, setelah mengetahui permasalahan yang ada peneliti membuktikan hipotesis mengenai pengaruh variabel independen yang terdiri dari variabel Performance Expectation, Effort Expectancy, Social Influence, and Facilitating Conditions terhadap variabel dependen, yaitu variabel Behavioral Intention and Use Behavior yang mengacu pada [3][5][6]. Berikut adalah hipotesis yang diajukan: 
H1 : Ekspektasi Kinerja berpengaruh positif terhadap Niat Perilaku pada penggunaan Aplikasi Wondroid.

H2 : Ekspektasi Usaha berpengaruh positif terhadap Niat Perilaku pada penggunaan Aplikasi Wondroid.

H3 : Pengaruh Sosial berpengaruh positif terhadap Behavioral Intention pada penggunaan Aplikasi Wondroid.

H4 : Kondisi-kondisi Memfasilitasi berpengaruh positif terhadap Perilaku Pengguna pada penggunaan Aplikasi Wondroid.

H5 : Niat Perilaku berpengaruh positif terhadap Perilaku Pengguna pada penggunaan Aplikasi Wondroid.

H6 : Ekspektasi Kinerja Ekspektasi Usaha dan Pengaruh Sosial secara bersama-sama berpengaruh signifikan terhadap Niat Perilaku pada penggunaan Aplikasi Wondroid.

H6

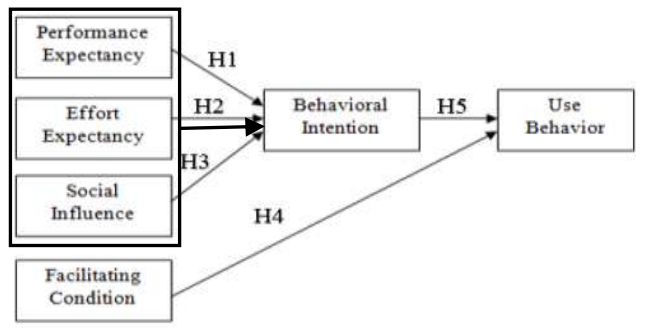

Gambar 2. Model Konseptual UTAUT [3][5][6]

Penyusunan Kuesioner

Alat pengumpul data pada penelitian ini adalah kuesioner. Hasil dalam tahapan ini adalah lembar kuesioner. Langkah-langkah dalam penyusunan kuesioner adalah:

a. Penentuan indikator pada variabel UTAUT

Penentuan indikator dilakukan untuk mengetahui isi dari kuesioner penelitian.

b. Penyusunan lembar kerja pertanyaan

Lembar kerja ini disusun setelah menentukan indikator apa saja yang digunakan dalam penelitian. Berupa pernyataan yang sesuai dengan indikator pada masing-masing variabel dan disesuaikan dengan lingkungan penelitian.

c. Penyeleksian kuesioner.

Penyeleksian kuesioner penelitian dilakukan dengan menguji validitas si kuesioner dan menguji reliabilitas konsistensi kuesioner.

HASIL PENELITIAN DAN PEMBAHASAN

Uji Kelayakan Kuesioner

Uji Validitas

Pengujian validitas wajib dilakukan untuk mengukur valid atau tidaknya suatu instrumen, (Ghozali, 2009). Teknik pengujian validitas menggunakan korelasi produk momen dengan taraf error 0,05 (5\%). Untuk uji validitas peneliti mengambil persentase $30 \%$ dari jumlah sampel (100) yaitu 30 pengguna, sehingga didapatkan nilai $r$ tabel 0,2913. Jika value $r$ tabel lebih besar dari value $r$ hitung dikatakan valid, jika nilai $r$ tabel lebih kecil dari nilai $\mathrm{r}$ hitung maka dinyatakan tidak valid. Atau bisa juga dengan melihat hasil signifikansi pada $\mathrm{r}$ hitung, jika signifikansi lebih kecil dari 0,05 maka item kuesioner tersebut valid. Hasil uji validitas tertera pada Tabel 2 .

Item kuesioner yang menunjukkan hasil tidak valid tidak dapat digunakan sebagai pernyataan pada kuesioner, maka item tersebut dapat diganti dengan pernyataan lain ataupun dihilangkan [8]. Dalam hal ini peneliti menghilangkan item nomor 10, sedangkan item nomor 15 pernyataan diganti. Sehingga keseluruhan item pernyataan berjumlah 22 pernyataan.

\section{Uji Reliabilitas}

Pengukuran kuesioner dilakukan pengujian. Jika kuesioner reliable maka jawaban dari kuesioner tersebut stabil jika dilakukan di lingkungan yang berbeda [4]. Suatu kuesioner dinyatakan reliable jika dapat dipertanggung jawabkan. Uji reliabilitas ini menggunakan Cronbach's Alpha. Untuk mengetahui tinggi rendahnya reliabilitas instrumen digunakan kriteria Cronbach's Alpha [4] yang dapat dilihat 
pada Tabel 1. Hasil output reliabilitas dapat dilihat dari nilai koefisien Cronbach's Alpha yang ditunjukkan pada Tabel 3.

Tabel 1. Parameter Cronbach's Alpha

\begin{tabular}{cc}
\hline Rentang & Keterangan \\
Reliabilitas & Sangat Reliable \\
\hline$>0,9$ & Reliable \\
$0,7-0,9$ & Cukup Reliabel \\
$0,4-0,7$ & Kurang Reliable \\
$0,2-04$ & Tidak Reliable \\
$<0,2$ & \\
\hline
\end{tabular}

Tabel 2. Output Uji Validitas

\begin{tabular}{ccccc}
\hline No. & $r_{\text {Hitun }}$ & $r_{\text {Tand }}$ & Sig. & Ket. \\
\hline PE1 & 0,462 & 0,2913 & 0,003 & Valid \\
PE2 & 0,560 & 0,2913 & 0,000 & Valid \\
PE3 & 0,416 & 0,2913 & 0,008 & Valid \\
PE 4 & 0,476 & 0,2913 & 0,003 & Valid \\
EE5 & 0,507 & 0,2913 & 0,001 & Valid \\
EE6 & 0,529 & 0,2913 & 0,001 & Valid \\
EE7 & 0,665 & 0,2913 & 0,000 & Valid \\
EE8 & 0,708 & 0,2913 & 0,000 & Valid \\
SI9 & 0,347 & 0,2913 & 0,024 & Valid \\
SI10 & 0,159 & 0,2913 & 0,188 & Tidak \\
SI11 & 0,487 & 0,2913 & 0,002 & Valid \\
SI12 & 0,387 & 0,2913 & 0,013 & Valid \\
FC13 & 0,360 & 0,2913 & 0,020 & Valid \\
FC14 & 0,639 & 0,2913 & 0,000 & Valid \\
FC15 & 0,208 & 0,2913 & 0,122 & Tidak \\
FC16 & 0,324 & 0,2913 & 0,033 & Valid \\
BI17 & 0,505 & 0,2913 & 0,001 & Valid \\
BI18 & 0,563 & 0,2913 & 0,000 & Valid \\
BI19 & 0,601 & 0,2913 & 0,000 & Valid \\
UB20 & 0,710 & 0,2913 & 0,000 & Valid \\
UB21 & 0,507 & 0,2913 & 0,001 & Valid \\
UB22 & 0,683 & 0,2913 & 0,000 & Valid \\
UB23 & 0,671 & 0,2913 & 0,000 & Valid
\end{tabular}

Tabel 3. Output Uji Reliabilitas

Output Cronbach's Jumlah Item

\begin{tabular}{cc} 
Alpha & Pernyataan \\
\hline 0,873 & 21 \\
\hline
\end{tabular}

Pengujian reliabilitas dibantu dengan aplikasi statistik SPSS v.23 dengan cara input hasil jawaban keseluruhan yang valid saja sejumlah 21 buah dan menghasilkan nilai Cronbach's Alpha sebesar 0,873 yang dapat dilihat pada Tabel 3. Tinggi rendahnya hasil Cronbach's Alpha dapat dilihat pada Tabel 1 yang ditunjukkan pada rentang 0,7 - 0,9. Sehingga reliabilitas item kuesioner dalam penelitian ini menunjukkan hasil yang reliable.

\section{Pengumpulan Data}

Deskripsi Responden

Deskripsi responden ditunjukkan pada Tabel 4. Berdasarkan Tabel 4, 61 orang berjenis kelamin laki-laki dengan persentase sebesar 61\%. Sedangkan responden yang berjenis kelamin perempuan sebesar 39 orang dengan persentase 39\%. Sehingga keseluruhan responden pada penelitian ini adalah berjenis kelamin laki-laki.

Deskripsi responden berdasarkan usia dapat dilihat pada Gambar 3. Berdasarkan grafik pada Gambar 3, dapat disimpulkan bahwa terdapat 4 responden yang memiliki persentase $4 \%$ berusia 23 tahun, sedangkan responden tertua terdapat 3 responden yang memiliki persentase $3 \%$ berusia 54 tahun. Selanjutnya usia responden yang terbanyak berada pada usia 45 tahun dengan jumlah 7 responden yang memiliki persentase 7\%. Responden paling sedikit berada pada usia 34,41 dan 44 tahun dengan jumlah responden masing-masing 3 orang yang berarti memiliki persentase 3\% dari total 100\%.

Deskripsi responden berdasarkan bidang pekerjaan responden dapat dilihat pada Gambar 4. Berdasarkan diagram lingkaran, dapat disimpulkan bahwa terdapat 2 bidang yang memiliki persentase paling tinggi diantara bidang yang lain yaitu bidang Sistem Informasi Manajemen (SIM) dan bidang Kehilangan Air (NRW) yang memberikan masingmasing kontribusi sebanyak $13 \%$ dari total $100 \%$. Sedangkan bidang yang memiliki persentase terendah adalah bidang Keuangan dan bidang Akuntansi yang masing-masing memberikan kontribusi 3\% dari total keseluruhan $100 \%$.

Tabel 4. Gender Responden

\begin{tabular}{ccc}
\hline Gender & Jumlah & $\%$ \\
\hline Laki-Laki & 61 & $61 \%$ \\
Perempuan & 39 & $39 \%$ \\
Total & 100 & $100 \%$
\end{tabular}




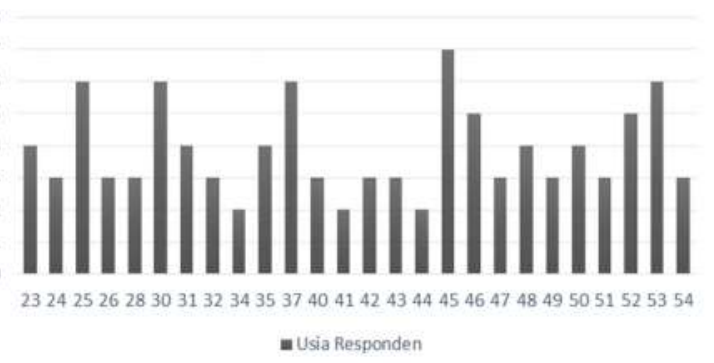

Gambar 3. Grafik Usia Responden

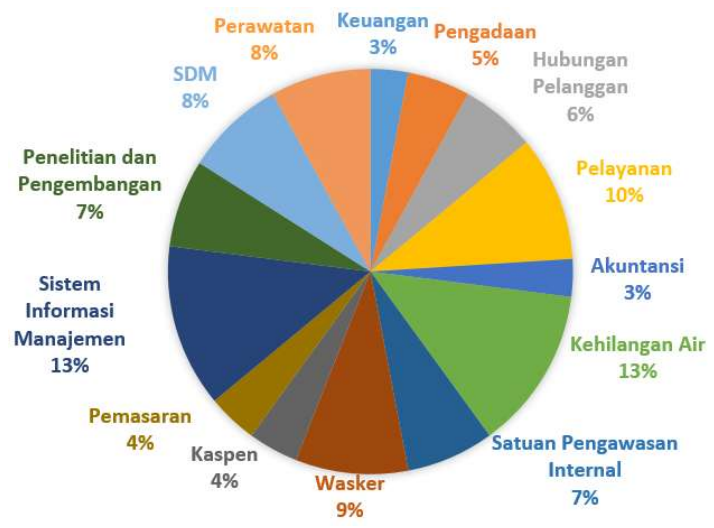

Gambar 4. Diagram Lingkaran Bidang Pekerjaan Responden

Analisis Hasil Pengumpulan Data Uji t (Uji Statistik Parameter Parsial)

Pengujian $t$ dilakukan untuk mengetahui pengaruh masing-masing variabel independen (Ekspektasi Kinerja, Ekspektasi Usaha dan Pengaruh Sosial) terhadap variabel dependen (Niat Perilaku dan Perilaku Pengguna) secara parsial. Hasil uji t dapat dilihat pada Tabel 5.

Tabel 5. Output Uji t

\begin{tabular}{|c|c|c|c|}
\hline Variabel & B & $t_{\text {tutunon }}$ & Sig. \\
\hline Performance & & & 0,929 \\
\hline $\begin{array}{l}\text { Expectancy } \\
\text { terhadap }\end{array}$ & 0,009 & 0,090 & \\
\hline $\begin{array}{l}\text { Behavioral } \\
\text { Intention }\end{array}$ & & & \\
\hline $\begin{array}{l}\text { Effort } \\
\text { Expectancy } \\
\text { terhadap }\end{array}$ & 0,413 & 4,205 & 0,000 \\
\hline $\begin{array}{l}\text { Behavioral } \\
\text { Intention }\end{array}$ & & & \\
\hline $\begin{array}{l}\text { Social Influence } \\
\text { terhadap } \\
\text { Behavioral }\end{array}$ & 0,223 & 2,190 & 0,031 \\
\hline
\end{tabular}

\begin{tabular}{llll}
$\begin{array}{l}\text { Intention } \\
\text { Facilitating } \\
\text { Conditions } \\
\text { terhadap Use }\end{array}$ & 0,576 & 5,800 & 0,000 \\
$\begin{array}{l}\text { Behavior } \\
\text { Behavioral } \\
\text { Intention }\end{array}$ & 0,328 & 2,784 & 0,006 \\
terhadap Use & & & \\
Behavior & & & \\
\hline
\end{tabular}

Pengujian dilakukan dengan membandingkan $t_{\text {Hitung }}$ dengan $t_{\text {Tabel }}$ ataupun dengan cara melihat nilai signifikansi. $\quad \mathrm{t}_{\text {Tabel }}$ didapatkan berdasarkan taraf signifikansi 0,025 dan df $=96$, sehingga didapatkan $\mathrm{t}_{\text {Tabel }} 1,985$. Variabel dinyatakan berpengaruh jika $\mathrm{t}_{\text {Hitung }}>\mathrm{t}_{\text {Tabel }^{\circ}}$. Sebaliknya dinyatakan tidak berpengaruh jika $t_{\text {Hitung }}<t_{\text {Tabel }}$. Pengambilan keputusan juga dapat dilihat dari nilai signifikansi, jika lebih kecil dari 0,05 dinyatakan berpengaruh, sebaliknya jika lebih besar dari 0,05 dinyatakan tidak berpengaruh.

\section{Uji F (Uji Statistik Parameter Simultan)} Pengujian $F$ dilakukan untuk mengetahui pengaruh variabel dependen (Ekspektasi Kinerja, Ekspektasi Usaha dan Pengaruh Sosial) terhadap variabel dependen (Niat Perilaku dan Perilaku Pengguna) secara simultan. Hasil uji $F$ dapat dilihat pada Tabel 6 .

Tabel 6. Output Uji F

\begin{tabular}{|c|c|c|c|}
\hline Model & $\begin{array}{l}\text { Degree } \\
\text { of } \\
\text { freedom }\end{array}$ & $\begin{array}{l}\text { Nilai F } \\
\text { hitung }\end{array}$ & $\begin{array}{c}\text { Signifikan } \\
\text { si }\end{array}$ \\
\hline Regression & 3 & 19.076 & $.000^{\mathrm{b}}$ \\
\hline Residual & 99 & & \\
\hline Total & 102 & & \\
\hline
\end{tabular}

Berdasarkan Tabel 6, dapat dilihat hasil dari signifikansi 0,000 dan perolehan $\mathrm{F}_{\text {Hitung }}$ sebesar 19,076 dengan nilai df pembilang 3 melalui penghitungan jumlah variabel dikurangi satu dan nilai df penyebut 96 didapatkan dengan cara jumlah responden dikurangi variabel penelitian (bebas dan terikat), maka diperoleh $\mathrm{F}_{\text {Tabel }}$ 2,70. Dari hasil analisis, hasil uji $\mathrm{F}_{\text {Hitung }}^{\text {Tabel }}$ bernilai 19,076 dimana lebih besar dari 2,70 , serta hasil signifikansi $0,000<$ 0,05 , sehingga dapat dikatakan bahwa variabel Ekspektasi Kinerja, Ekspektasi 
Usaha dan Pengaruh Sosial secara bersama-sama berpengaruh terhadap Niat Perilaku.

\section{Uji Koefisien Determinasi (Adjusted R Square)}

Untuk dapat mengetahui kontribusi yang diberikan variabel independen terhadap variabel dependen, dilakukan uji koefisien determinasi yang ditunjukkan dalam persentase. Dari output Model Summary nilai yang digunakan adalah Adjusted $\mathrm{R}$ Square yang menunjukkan nilai koefisien determinasi sebesar 0,347 atau 34,7\%. Dapat diartikan bahwa variabel Performance Expectancy, Effort Expectancy dan Social Influence dapat mempengaruhi Behavioral Intention sebesar 34,7\%. Sedangkan 65,3\% sisanya dijelaskan pada variabel lain yang tidak digunakan dalam penelitian. Outputnya ditunjukkan pada Tabel 7. Sedangkan kontribusi variabel dependen yang dipengaruhi variabel independen ditunjukkan pada Tabel 8 dengan melihat nilai R Square Change.

Tabel 8. Hasil Uji R Square Change

\begin{tabular}{|c|c|c|c|c|c|c|c|c|c|}
\hline \multirow[b]{2}{*}{ Model } & \multirow[b]{2}{*}{$\mathrm{R}$} & \multirow[b]{2}{*}{$\begin{array}{c}\mathrm{R} \\
\text { Square }\end{array}$} & \multirow{2}{*}{$\begin{array}{c}\text { Adjusted } \\
\text { R } \\
\text { Square }\end{array}$} & \multirow[b]{2}{*}{$\begin{array}{l}\text { Std. Error of } \\
\text { the Estimate }\end{array}$} & \multicolumn{5}{|c|}{ Change Statistics } \\
\hline & & & & & $\begin{array}{l}\text { R Square } \\
\text { Change } \\
\end{array}$ & F Change & df1 & df2 & \begin{tabular}{|c|} 
Sig. F \\
Change \\
\end{tabular} \\
\hline 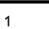 & $.416^{\mathrm{a}}$ & .173 & .165 & 1.613 & .173 & 21.092 & 1 & 101 & .000 \\
\hline & $.579^{b}$ & .336 & .322 & 1.453 & .163 & 24.510 & 1 & 100 & .000 \\
\hline 3 & $.605^{c}$ & .366 & .347 & 1.426 & .031 & 4.797 & 1 & 95 & (037 \\
\hline 4 & $.647^{\mathrm{d}}$ & .418 & .412 & 1.809 & .418 & 72.591 & 1 & 101 & .000 \\
\hline 5 & $.678^{\mathrm{e}}$ & .460 & .449 & 1.751 & .042 & 7.753 & 1 & 100 & 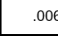 \\
\hline
\end{tabular}

Berdasarkan pada Tabel 8 dapat dilihat pada kolom $\mathrm{R}$ Square Change bahwa Performance Expectancy memiliki $17,3 \%$ mempengaruhi Behavioral Intention, Effort Expectancy memiliki $16,3 \%$ dalam mempengaruhi Behavioral Intention, Social Influence memiliki 3,1\% dalam mempengaruhi Behavioral Intention, Facilitating Conditions memiliki $41,8 \%$ dalam mempengaruhi Use Behavior, Behavioral Intention memiliki 4,2\% dalam mempengaruhi Use Behavior.

Pembuktian Hipotesis

Pembuktian Hipotesis 1

Uji t dilakukan untuk membuktikan hipotesis 1 dengan cara membandingkan $t_{\text {Hitung }}$ dengan $t_{\text {Tabel. }}$ Jika $\mathrm{t}_{\text {Hitung }}$ lebih besar dari $\mathrm{t}_{\text {Tabel }}$ dan tingkat signifikansi kurang dari 0,05, maka dapat dinyatakan $\mathrm{H}_{0}$ ditolak dan $\mathrm{H}_{3}$ diterima. Sehingga diperoleh hasil bahwa nilai $t_{\text {Hitung }}$ pada variabel Performance Expectancy $(-0,090)$ lebih kecil dari $\mathrm{t}_{\text {Tabel }}(1,985)$. Sementara tingkat signifikansi $(0,929)$ lebih besar dari 0,05 , sehingga dapat dinyatakan $\mathrm{H}_{0}$ diterima dan $\mathrm{H}_{1}$ ditolak.
$\mathrm{H}_{0}$ : Peformance Expectancy tidak berpengaruh positif terhadap Behavioral Intention pada penggunaan Aplikasi Work Order Android (Wondroid).

\section{Pembuktian Hipotesis 2}

Uji t dilakukan untuk membuktikan hipotesis 2 dengan cara membandingkan $t_{\text {Hitung }}$ dengan $t_{\text {Tabel }}$. Apabila $t_{\text {Hitung }}$ lebih besar dari $t_{\text {Tabel }}$ dan tingkat signifikansi kurang dari 0,05 , maka dapat dinyatakan $\mathrm{H}_{0}$ ditolak dan $\mathrm{H}_{2}$ diterima. Dari hasil uji t yang telah dilakukan, maka diperoleh hasil bahwa nilai $t_{\text {Hitung }}$ pada variabel Effort Expectancy $(4,205)$ lebih besar dari $t_{\text {Tabel }}$ $(1,985)$. Sementara tingkat signifikansi

Tabel 7. Ouput Uji Adjusted R Square

\begin{tabular}{ccccc}
\hline Model & $\mathrm{R}$ & $\begin{array}{c}\mathrm{R} \\
\text { Square }\end{array}$ & $\begin{array}{c}\text { Adjusted } \\
\text { R Square }\end{array}$ & $\begin{array}{c}\text { Std. Error } \\
\text { of the } \\
\text { Estimate }\end{array}$ \\
\hline 1 & $.605^{\mathrm{a}}$ & .366 & .347 & 1.426 \\
\hline $\begin{array}{l}0,000) \\
\text { dapat debih kecil dari }\end{array}$ & 0,05 , & sehingga \\
diterima.
\end{tabular}

$\mathrm{H}_{2}$ : Effort Expectancy berpengaruh positif terhadap Behavioral Intention pada penggunaan Aplikasi Work Order Android (Wondroid).

Pembuktian Hipotesis 3

Uji $t$ dilakukan untuk membuktikan hipotesis 3 dengan cara membandingkan $t_{\text {Hitung }}$ dengan $t_{\text {Tabel }}$. Apabila $t_{\text {Hitung }}$ lebih besar dari $t_{\text {Tabel }}$ dan tingkat signifikansi kurang dari 0,05 , maka dapat dinyatakan $\mathrm{H}_{0}$ ditolak dan $\mathrm{H}_{3}$ diterima. Dari hasil uji t yang telah dilakukan, maka diperoleh hasil bahwa nilai $t_{\text {Hitung }}$ pada variabel Social Influence $(2,190)$ lebih besar dari $t t_{\text {Tabel }}(1,985)$. Sementara tingkat signifikansi $(0,031)$ lebih kecil dari 0,05, sehingga dapat dinyatakan $\mathrm{H}_{0}$ ditolak dan $\mathrm{H}_{3}$ diterima. 
$\mathrm{H}_{3}$ : Social Influence berpengaruh positif terhadap Behavioral Intention pada penggunaan Aplikasi Work Order Android (Wondroid).

\section{Pembuktian Hipotesis 4}

Uji $t$ dilakukan untuk membuktikan hipotesis 4 dengan cara membandingkan $t_{\text {Hitung }}$ dengan $t_{\text {Tabel }}$. Apabila $t_{\text {Hitung }}$ lebih besar dari $t_{\text {Tabel }}$ dan tingkat signifikansi kurang dari 0,05, maka dapat dinyatakan $\mathrm{H}_{0}$ ditolak dan $\mathrm{H}_{4}$ diterima. Dari hasil uji t yang telah dilakukan, maka diperoleh hasil bahwa nilai $t_{\text {Hitung }}$ pada variabel Facilitating Conditions $(5,800)$ lebih besar dari $\mathrm{t}_{\text {Tabe }}$ $(1,984)$. Sementara tingkat signifikansi $(0,029)$ lebih kecil dari 0,05 , sehingga dapat dinyatakan $\mathrm{H}_{0}$ ditolak dan $\mathrm{H}_{4}$ diterima.

$\mathrm{H}_{4}$ : Facilitating Conditions berpengaruh positif terhadap Use Behavior pada penggunaan Aplikasi Work Order Android (Wondroid).

\section{Pembuktian Hipotesis 5}

Uji $t$ dilakukan untuk membuktikan hipotesis 5 dengan cara membandingkan $t_{\text {Hitung }}$ dengan $t_{\text {Tabel }}$. Apabila $t_{\text {Hitung }}$ lebih besar dari $t_{\text {Tabel }}$ dan tingkat signifikansi kurang dari 0,05 , maka dapat dinyatakan $\mathrm{H}_{0}$ ditolak dan $\mathrm{H}_{5}$ diterima. Dari hasil uji t yang telah dilakukan, maka diperoleh hasil bahwa nilai $t_{\text {Hitung }}$ pada variabel Behavioral Intention $(2,784)$ lebih besar dari $t_{\text {Tabel }}$ $(1,984)$. Sementara tingkat signifikansi $(0,006)$ lebih kecil dari 0,05 , sehingga dapat dinyatakan $\mathrm{H}_{0}$ ditolak dan $\mathrm{H}_{5}$ diterima.

$\mathrm{H}_{5}$ : Behavioral Intention berpengaruh positif terhadap Use Behavior pada penggunaan Aplikasi Work Order Android (Wondroid).

\section{Pembuktian Hipotesis 6}

Uji F dilakukan untuk membuktikan hipotesis 6 dengan cara membandingkan $\mathrm{F}_{\text {Hitung }}$ dengan $\mathrm{F}$ Tabel: Apabila $\mathrm{F}_{\text {Hitung }}$ lebih besar dari $\mathrm{F}_{\text {Tabel }}$ dan tingkat signifikansi kurang dari 0,05 , maka dapat dinyatakan $\mathrm{H}_{0}$ ditolak dan $\mathrm{H}_{6}$ diterima. Dari hasil uji F yang telah dilakukan, maka diperoleh hasil bahwa nilai $\mathrm{F}_{\text {Hitung }}$ pada variabel Behavioral Intention $(19,076)$ lebih besar dari F tabel (2,70). Sementara tingkat signifikansi $(0,000)$ lebih kecil dari 0,05, sehingga dapat dinyatakan $\mathrm{H}_{0}$ ditolak dan $\mathrm{H}$ diterima.

$\mathrm{H}_{6}$ : Performance Expectancy, Effort Expectancy dan Social Influence secara bersama-sama berpengaruh signifikan terhadap Behavioral Intenion pada penggunaan Aplikasi Work Order Android (Wondroid).

\section{KESIMPULAN}

Berdasarkan hasil penelitian yang telah dilakukan peneliti membuat kesimpulan dan saran sebagai berikut:

1. Berdasarkan hasil analisis deskriptif didapatkan bahwa aplikasi Work Order Android (Wondroid) mendapatkan tanggapan "setuju" dari para pengguna $(3,41-4,20)$.

2. Dari hasil pengujian hipotesis yang telah dilakukan bahwa terdapat hasil yang positif dan negatif yang dapat dijabarkan sebagai berikut:

a. Performance Expectancy tidak terbukti berpengaruh positif terhadap Behavioral Intention pada penggunaan Wondroid.

b. Effort Expectancy terbukti berpengaruh positif terhadap Behavioral Intention pada penggunaan Wondroid.

c. Social Influence terbukti berpengaruh positif terhadap Behavioral Intention pada penggunaan Wondroid.

d. Facilitating Conditions terbukti berpengaruh positif terhadap Use Behavior pada penggunaan Wondroid.

e. Performance Expectancy, Effort Expectancy dan Social Influence terbukti mempengaruhi Behavioral Intention secara simultan pada penggunaan Wondroid.

3. Berdasarkan hasil uji koefisien determinasi, pengaruh variabel independen (bebas) terhadap variabel dependen (terikat) dapat dijabarkan sebagai berikut:

a. Performance Expectancy, Effort Expectancy dan Social Influence mempengaruhi Behavioral Intention sebesar 34,7\%. 
b. Performance Expectancy memiliki $17,3 \%$ dalam mempengaruhi Behavioral Intention.

c. Effort Expectancy memiliki 16,3\% dalam mempengaruhi Behavioral Intention.

d. Social Influence memiliki 3,1\% dalam mempengaruhi Behavioral Intention.

e. Facilitating Conditions memiliki $41,8 \%$ dalam mempengaruhi Use Behavior.

f. Behavioral Intention memiliki $4,2 \%$ dalam mempengaruhi Use Behavior.

Adapun saran dalam penelitian ini sebagai berikut:

1. Menambahkan variabel moderasi (age, gender, experience, and voluntariness of use).

2. Berdasarkan hasil penelitian telah diketahui, bahwa variabel Performance Expectancy (harapan kinerja) tidak berpengaruh positif terhadap Behavioral Intention (niat berperilaku), sehingga dapat dikatakan bahwa pengguna tidak merasakan manfaat dalam menggunakan Wondroid untuk dapat meningkatkan kinerjanya. Berkaitan dengan hal tersebut, hendaknya pihak SIM PDAM Kota Malang perlu mengadakan sosialisasi secara berkala kepada para pegawai agar mampu meningkatkan pemahaman mengenai adanya manfaat jika menggunakan Wondroid, serta perlunya ketentuan-ketentuan pada salah satu fitur aplikasi Wondroid contohnya fitur foto realisasi pekerjaan.

Referensi

Fandhilah. (2015). "Model Penerimaan dan Penggunaan Program Aplikasi Akuntansi Pada Siswa SMK Studi Kasus SMK Yadika 1 dan SMK Yadika 2 Jakarta Barat”. Jurnal Bianglala Informatika. Vol. 2 No. 2.

Farabi, Nur Ali. (2016). "Analisis Penerapan Sistem Informasi ZISW dengan Menggunakan Metode UTAUT". Indonesian Journal on Computer and
Information Technology. Vol. 3 No. 2.

Iriani, Siska. Suyanto, M. Amborowati, Armadyah. (2014). "Pengujian Sistem Informasi Pengelolaan Keuangan Daerah Berbasis Web Kabupaten Pacitan Dengan Menggunakan Unified Theory of Acceptance and Use of Technology (UTAUT)". IJINS Indonesian Journal on Networking and Security. Vol. 3 No.2.

Kusuma, Wahyu Andhika. Noviasari, Vebrian. Marthasari, Gita Indah. (2016). "Analisis Usability Dalam User Experience Pada Sistem KRS-Online UMM Menggunakan USE Questionnaire". J NTETI. Vol. 5, No. 4.

S. Dasgupda, M. Haddad, P. Weiss, E. Bermudez. (2007). "User Acceptance of Case Tools in System Analysis and Design: An Empirical Study," Journal of Informatics Education Research, Vol. 9, hal. 51-78.

Tan, Paul Juinn Bing. (2013). “Student's Adoptions and Attitudes Towards Electronic Placement Tets: A UTAUT Analysis". American Journal of Computer Technology and Application. Vol. 1, No. 1.

V. Venkatesh, M.G. Morris, G.B. Davis, F.D. Davis. (2003). "User Acceptance of Information Technology: Toward A Unified View" MIS Quarterly, Vol. 27, pp. 425-478.

Matondang, Z. (2009). "Validitas dan Reliabilitas Suatu Instrumen Penelitian". Jurnal Tabularasa PPS UNIMED. Vol. 6 No. 1. hal. 93.

Sugiyono. 2011. "Metode Penelitian Pendidikan (Pendekatan Kuantitatif, Kualitatif dan R\&D)". Bandung: Alfabeta.

Matondang, Z. (2009). "Validitas Dan Reliabilitas Suatu Instrumen Penelitian". Jurnal Tabularasa PPS UNIMED. Vol. 6 no. 1. Hal. 93. 